\section{Fla. 8638B and Fla. 8624 Tomato Breeding Lines with Begomovirus Resistance Genes ty-5 Plus Ty-6 and Ty-6, respectively}

\author{
John W. Scott and Samuel F. Hutton ${ }^{1}$ \\ Institute of Food and Agricultural Sciences (IFAS), University of Florida \\ Gulf Coast Research and Education Center, 14625 CR 672, Wimauma, \\ FL 33598
}

\section{Joshua H. Freeman \\ Institute of Food and Agricultural Sciences (IFAS), University of Florida, North Florida Research and Education Center, 155 Research Road, Quincy, FL 32351}

Additional index words. crimson, high lycopene, Solanum lycopersicum, tomato, yellow leaf curl virus resistance, tomato mottle virus resistance

Begomoviruses, vectored by the sweetpotato whitefly (Bemisia tabaci), are a major threat to tomato (Solanum lycopersicum) production in many regions around the world. Of the many strains of Begomoviruses, those that cause Tomato yellow leaf curl virus (TYLCV) are among the most destructive, the most widespread, and the most well known. TYLCV-resistant cultivars are commercially available in many production regions, and most of these use the dominant Ty-1 gene. Generally, tomato growers do not like the TYLCV-resistant cultivars as well as susceptible cultivars due to linkage drag effects that reduce marketable yield, increase foliar disease infections to diseases such as early blight (Alternaria solani) and/or bacterial spot (Xanthomonas spp.). Furthermore, the $T y-1$ gene is not effective against some TYLCV strains and some other Begomoviruses, such as Tomato mottle virus (ToMoV). To date, several additional resistance genes have been identified including $T y-2, T y-3$, $T y-4, t y-5$, and recently $T y-6$ (Hutton et al., 2012; Hutton and Scott, 2014). Whereas, the inheritance of these genes has generally been characterized in crosses with susceptible parents, epistatic relationships between resistance genes are not well understood. Combining resistance genes often provides higher levels and more broadly based resistance against various Begomoviruses (Mejia et al., 2010; Vidavski, 2007). For future breeding of cultivars with high levels of durable resistance, it will be beneficial for tomato breeders to use and/or combine multiple resistance genes. The present breeding line releases combine good horticultural and

Received for publication 1 Apr. 2015. Accepted for publication 24 Apr. 2015.

We thank Dolly Cummings, Tim Davis, Jose Diaz, and Rudy Jones for technical support.

${ }^{1}$ Corresponding author. E-mail: sfhutton@ufl.edu. yield characteristics with Begomovirus resistance genes that have not yet been widely used commercially. These should prove useful either directly as parent lines in commercial hybrids or as sources of resistance for tomato breeders to develop their own parents for commercially acceptable hybrid cultivars.

\section{Origin}

Fla. $8638 \mathrm{~B}$. The pedigree of Fla. $8638 \mathrm{~B}$ is in Fig. 1. The source of the $T y-6$ gene was Solanum chilense accession LA1938. Embryo rescue was used to obtain a plant from the cross with Fla. 7309. After the first backcross $\left(\mathrm{F}_{1} \mathrm{BC}_{1}\right)$ to Fla. 7412 , selection to the $\mathrm{F}_{8}$ generation under inoculation with the bipartite geminivirus ToMoV resulted in a resistant line with indeterminate plants and orange fruit color. Meanwhile it was determined that the $\mathrm{F}_{1}$ cultivar Tyking had a good level of ToMoV resistance. An $\mathrm{F}_{2}$ of 'Tyking' was grown and there was no segregation for the level of ToMoV resistance, so a bulk of pollen was used for crossing with the $\mathrm{F}_{8}$ to save space. line. From this cross, an $\mathrm{F}_{4}$ line with a high level of ToMoV resistance, determinate plant habit, and red fruit color was obtained. We now know that this line had the recessive ty-5 gene derived from 'Tyking' (Hutton et al., 2012). The next crosses were to breeding lines Fla. 7801, Fla. 7722, and $\mathrm{NC}_{111 \mathrm{~F}_{2}}$ (98), a line from North Carolina State University. Finally, the $F_{3}$ line from this was crossed to Fla. 8059 , a crimson $\left(\operatorname{og}^{\mathrm{c}}\right)$ inbred that is a parent in 'Fla. 8153' (TastiLee $\left.^{\circledR}\right)$ (Scott et al., 2008). After several generations of selection under TYLCV inoculation, seed of Fla. 8638B was bulked in the $\mathrm{F}_{14}$ generation.

Fla 8624. The pedigree of Fla. 8624 is in Fig. 2. The Ty- 6 gene could have been derived from either $S$. chilense accession LA2779 or LA1938. For the portion of the pedigree related to LA2779, the earliest crosses were described in the release of Fla. 8923 (Hutton et al., 2015). The Fla. 8624 pedigree diverged from Fla. 8923 following the cross with a Begomovirus susceptible Israeli greenhouse tomato inbred; whereas an $\mathrm{F}_{4}$ selection from this cross was used in the development of Fla. 8923, an $\mathrm{F}_{8}$ selection was used for Fla. 8624. This $\mathrm{F}_{8}$ was crossed to Fla. 7906, a heat-tolerant breeding line. Plants in the $F_{2}$ to $F_{4}$ generations were alternately screened for resistance to TYLCV and ToMoV, and $\mathrm{F}_{4}$ pollen was then used in a cross with Fla. 7781, a crimson $\left(\operatorname{og}^{\mathrm{c}}\right)$ line with resistance to fusarium crown rot (Scott and Jones, 2000). The $\mathrm{F}_{5}$ from this was next crossed to Fla. 8125, an $\mathrm{F}_{5}$ crimson line derived from a cross between NC84173 and Fla. 7781 (Gardner, 1992). This led to the $F_{4}$ line, Fla. 8379B, which was crossed to Fla. 8472 in fall 2005, and this was the final cross that resulted in Fla. 8624. The Fla. 8472 pedigree is similar to that of Fla. $8638 \mathrm{~B}$ (Fig. 1). Both came from the cross of Fla. 7722 with an $\mathrm{F}_{3}$ line, but with Fla. $8638 \mathrm{~B}$ the subsequent cross was made in the $F_{3}$ generation, whereas with Fla. 8624 the same $F_{3}$ was advanced to the $F_{6}$ before the next cross. Fla. 8472 is a crimson, TYLCV-resistant inbred. Fla. 8624 carries the $T y-6$ gene but does not have the ty-5 gene. Seed of Fla. 8624 was bulked in the $\mathrm{F}_{6}$ generation.

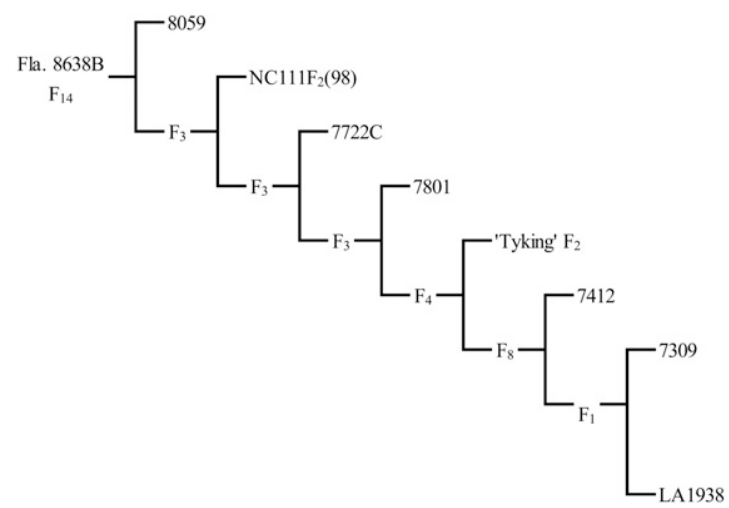

Fig. 1. Pedigree of Fla. 8638B. All 7000 and 8000 numbered lines have a Fla. prefix that has been omitted 


\section{Description}

Fla. 8638 B. Fla. 8638 B has a determinate $(s p)$ vine with good leaf cover to protect the fruit. Maturity is midseason. The mediumsized fruit have jointed pedicels and immature fruit have uniform green shoulders $(u)$. Fruit are a flat-round shape with smooth, stellate blossom scars. The ripe fruit are firm and have a good exterior color similar to most tomato cultivars grown commercially in Florida. Interior color is a deep red due to the crimson gene. In Spring 2014 trial at Balm, FL, the total marketable yield was significantly less than that of 'Florida 47' but did not differ from Tasti-Lee ${ }^{\circledR}$ and 'Sanibel' (Table 1). Yield of extra large fruit was significantly less than that of 'Florida 47' and 'Sanibel' but did not differ from TastiLee ${ }^{\circledR}$. Fruit size of Fla. 8638 B was significantly less than that of 'Sanibel', similar to 'Florida 47' and significantly greater than that of Tasti-Lee ${ }^{\circledR}$. In the Spring 2014 trial at Quincy, FL, the total marketable and extra large yields for Fla. 8638B were less than the commercial hybrids 'BHN 602' and 'Florida 47' (Table 2). The fruit size of Fla. 8638B was significantly less than that of 'BHN 602', but did not differ from that of 'Florida 47'. Over several field plantings flavor was rated a 3 by the authors on a subjective $1-5$ scale where higher numbers indicated better flavor. On this scale, a typical score for 'Florida 47' would be a 2, 'Sanibel' would be a 2 or less, whereas Tasti-Lee ${ }^{\circledR}$ would be a 4 .

Fla 8624. Fla. 8624 has a determinate $(s p)$ vine with good leaf cover to protect the fruit. Fruit pedicels are jointed, and immature fruit have uniform green shoulders $(u)$. Fruit are a flat-round shape, with smooth, stellate blossom scars. The fruit shape has been consistently good, and the shoulders ripen with a particularly nice sheen with excellent tolerance to all types of cracking. The ripe fruit have an exterior color that is a deeper red than many cultivars grown in Florida. The interior color is a deep red due to the crimson gene. Maturity is medium to late season. In the Spring 2014 Balm, FL trial, the later maturity of 8624 resulted in significantly lower total marketable yield for Fla. 8624 than the other trial entries (Table 1). Yield of extra large fruit was significantly less than that of 'Florida 47' and 'Sanibel', but did not differ from that of Tasti-Lee ${ }^{\circledR}$ and Fla. 8638B. Overall fruit size is medium to large; in Spring 2014 at Balm it was similar to that of 'Florida 47' and 'Sanibel' and larger than that of Tasti-Lee ${ }^{\circledR}$ (Table 1). In the Spring 2014 Quincy trial, total marketable yield, extra large yield, and fruit size for Fla. 8624 were equivalent to the commercial hybrids 'BHN 602' and 'Florida 47' (Table 2). Flavor of Fla. 8624 has been very good under wide-ranging conditions and would generally be rated a 4 or more by the authors using the scale described above.

\section{Disease Resistance}

Fla. 8638 B. Fla. 8638 B is resistant to fusarium wilt races 1 and 2 (Fusarium

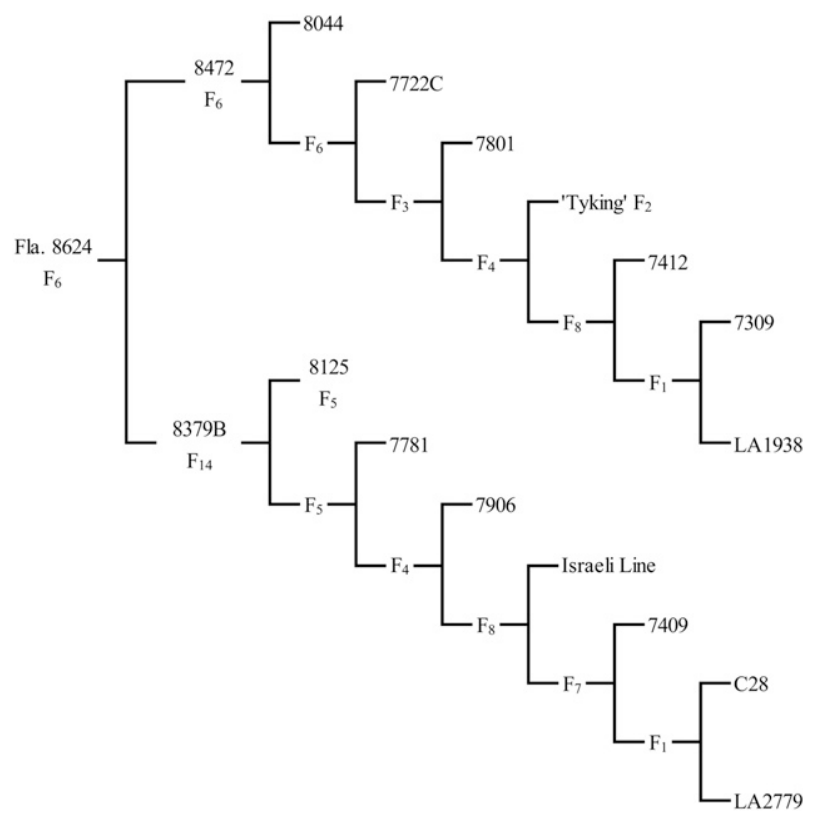

Fig. 2. Pedigree of Fla. 8624 . All 7000 and 8000 numbered lines have a Fla. prefix that has been omitted to save space.

Table 1. Total and extra large marketable yield, fruit size, and culls in Spring 2014 at Balm, FL for tomato Begomovirus-tolerant inbreds Fla. 8624, Fla. 8638B, and Fla. 8923 compared with three tomato hybrids that are commercially grown.

\begin{tabular}{|c|c|c|c|c|}
\hline \multirow[b]{2}{*}{ Genotype } & \multicolumn{2}{|c|}{ Marketable yield (11.4 kg cartons $/ \mathrm{ha}$ ) } & \multirow[b]{2}{*}{ Fruit size $(\mathrm{g})$} & \multirow[b]{2}{*}{ Culls ( $\%$ by wt } \\
\hline & Total & Extra large & & \\
\hline Florida 47 & $3,361 \mathrm{a}^{\mathrm{z}}$ & $2,511 \mathrm{a}$ & 198 bc & $23 \mathrm{c}$ \\
\hline Tasti-Lee $^{\circledR}$ & $3,022 \mathrm{ab}$ & $1,456 \mathrm{bc}$ & $156 \mathrm{~d}$ & $17 \mathrm{c}$ \\
\hline Sanibel & $2,707 \mathrm{a}-\mathrm{c}$ & $2,356 \mathrm{a}$ & $224 \mathrm{~b}$ & $41 \mathrm{a}$ \\
\hline Fla. 8638 B & $2,194 \mathrm{bc}$ & $1,552 \mathrm{bc}$ & $187 \mathrm{c}$ & $27 \mathrm{~b}$ \\
\hline Fla. 8923 & $2,087 \mathrm{c}$ & $2,053 \mathrm{ab}$ & $278 \mathrm{a}$ & $34 \mathrm{ab}$ \\
\hline Fla. 8624 & $1,234 \mathrm{~d}$ & $997 \mathrm{c}$ & $210 \mathrm{bc}$ & $26 \mathrm{bc}$ \\
\hline
\end{tabular}

${ }^{\mathrm{z}}$ Mean separation in columns by Duncan's multiple range test at $P \leq 0.05$.

Table 2. Total and extra large marketable yield, fruit size and culls in Spring 2014 at Quincy, FL for tomato Begomovirus-tolerant inbreds Fla. 8624 and Fla. 8638B compared with two tomato hybrids that are commercially grown.

\begin{tabular}{|c|c|c|c|c|}
\hline \multirow[b]{2}{*}{ Genotype } & \multicolumn{2}{|c|}{ Marketable yield (11.4 kg cartons/ha) } & \multirow[b]{2}{*}{ Fruit size (g) } & \multirow[b]{2}{*}{ Culls (\% by wt) } \\
\hline & Total & Extra large & & \\
\hline$\overline{\mathrm{BHN}} 602$ & $2,682 \mathrm{a}^{\mathrm{z}}$ & $2,116 \mathrm{a}$ & $230 \mathrm{a}$ & 25 \\
\hline Fla. 8624 & $2,378 \mathrm{a}$ & $2,111 \mathrm{a}$ & $246 \mathrm{a}$ & 26 \\
\hline Florida 47 & $2,297 \mathrm{a}$ & $1,907 \mathrm{a}$ & $215 \mathrm{ab}$ & 28 \\
\hline Fla. 8638B & $1,737 \mathrm{~b}$ & $1,225 \mathrm{~b}$ & $185 \mathrm{~b}$ & $24 \mathrm{NS}$ \\
\hline
\end{tabular}

${ }^{\mathrm{z}}$ Mean separation in columns by least significant difference test at $P \leq 0.05$.

NS = nonsignificant.

Table 3. Tomato yellow leaf curl virus (TYLCV) and Tomato mottle virus (ToMoV) disease severity for tomato genotype inoculated at the seedling stage at the Gulf Coast Research and Education Center, Spring 2014.

\begin{tabular}{lccc}
\hline Genotype & Begomovirus resistance gene & TYLCV & ToMoV \\
\hline Horizon & - & $3.9 \mathrm{a}^{\mathrm{y}}$ & $3.3 \mathrm{~b}$ \\
Fla. 8624 & $T y-6$ & $1.8 \mathrm{~b}$ & $0.8 \mathrm{~d}$ \\
Tygress & $T y-1 /+$ & $1.8 \mathrm{~b}$ & $3.0 \mathrm{bc}$ \\
Fla. 8638B & $T y-6$, ty-5 & $0.7 \mathrm{c}$ & $0.9 \mathrm{~d}$ \\
Fla. 8923 & $T y-3$ & $2.0 \mathrm{~b}$ & $2.7 \mathrm{c}$ \\
Fla. 8680 & $T y-3, T y-6$ & $0.3 \mathrm{c}$ & $0.1 \mathrm{~d}$ \\
TAMU 5 & $T y-2$ & $0.0 \mathrm{~d}$ & $3.9 \mathrm{a}$ \\
\hline
\end{tabular}

${ }^{\mathrm{z} R a t e d}$ at $66 \mathrm{~d}$ after inoculation began on a $0-4$ scale where lower number indicated less disease, for scale and inoculation information see Hutton et al. (2012).

${ }^{y}$ Mean separation in columns by Duncan's multiple range test at $P \leq 0.05$. 
oxysporum f. sp. lycopersici), gray leafspot (Stemphyllium sp.) and verticillium wilt race 1 (Verticillium dahliae). The primary disorders seen have been zippering and graywall. It has a high level of resistance to TYLCV that was significantly less than that of TAMU 5 ( $T y-2$ gene), similar to that of Fla. 8680 ( $T y-3$ and $T y-6$ genes), and more resistant than the other genotypes tested (Table 3 ). On the disease severity scale used, a score of 1 indicates symptoms that can be seen only on close inspection. For the bipartite geminivirus ToMoV; Fla. 8638B, Fla. 8624, and Fla. 8680 had a similar high level of resistance that was significantly better than all the other trial entries. Based on past experience, the high level of resistance of Fla. 8638B and Fla. 8680 to both viruses indicates their resistance may be effective against a wide range of Begomoviruses.

Fla. 8624. Fla. 8624 is resistant to fusarium wilt races 1 and 2 and gray leafspot. The primary disorder seen has been zippering. It has a high level of resistance to graywall. Fla. 8624 has an intermediate level of resistance to TYLCV; similar to 'Tygress' (Ty-1/+ gene) and Fla. 8923 (Ty-3 gene), less than
TAMU 5, Fla. 8680, and Fla. 8638B, but better than the susceptible control 'Horizon' (Table 3). For ToMoV, as stated above, Fla. 8624 was in the most resistant group. Thus, it appears that the $T y-6$ gene is more effective against ToMoV than TYLCV. The best use of Ty- 6 appears to be in combination with other Begomovirus resistance genes such as ty-5 (Fla. 8638B) or Ty-3 (Fla. 8680).

\section{Availability}

Fla. 8624 and Fla. 8638B are inbred breeding line releases. Seed distribution is controlled by Florida Foundation Seed Producers, P.O. Box 309, Greenwood, FL 32443. Initial seed requests should be made to S.F. Hutton.

\section{Literature Cited}

Gardner, R.G. 1992. 'Mountain Spring' tomato; NC 8276 and NC 84173 tomato breeding lines. HortScience 27:1233-1234.

Hutton, S.F., Y. Ji, and J.W. Scott. 2015. Fla. 8923 ; a tomato breeding line with begomovirus resistance gene $T y-3$ in a 70-kb Solanum chilense introgression. HortScience 50:1257-1259.
Hutton, S.F. and J.W. Scott. 2014. Ty-6, a major begomovirus resistance gene located on chromosome 10. Rept. Tomato Genet. Coop. 64:14-18.

Hutton, S.F., J.W. Scott, and D.J. Schuster. 2012. Recessive resistance to Tomato yellow leaf curl virus from the tomato cultivar Tyking is located in the same region as $T y-5$ on chromosome 4. HortScience 47:324-327.

Mejia, L., R.E. Teni, B.E. Garcia, A.C. Fulladolsa, and L. Mendez. 2010. Preliminary observations on the effectiveness of five introgressions for resistance to begomoviruses in tomatoes. Rept. Tomato Genet. Coop. 60:41-53.

Scott, J.W., E.A. Baldwin, H.J. Klee, J.K. Brecht, S.M. Olson, J.A. Bartz, and C.A. Sims. 2008. Fla. 8153 hybrid tomato; Fla. 8059 and Fla. 7907 breeding lines. HortScience 43:22282230.

Scott, J.W. and J.P. Jones. 2000. Fla. 7775 and Fla. 7781: Tomato breeding lines resistant to Fusarium crown and root rot. HortScience 35:11831184.

Vidavski, F. 2007. Exploitation of resistance genes found in wild tomato species to produce resistant cultivars; pile up of resistant genes, p. 363-372. In: H. Czosnek (ed.). Tomato yellow leaf curl virus disease: Management, molecular biology, breeding for resistance. Springer, Dordrecht, The Netherlands. 